\title{
Morphological response and genetic variability of four species of chili pepper (Capsicum spp.) under infection of pepper yellow leaf curl virus
}

\author{
TRI WAHONO DYAH AYU SAYEKTI ${ }^{1, \vartheta}$, MUHAMAD SYUKUR ${ }^{3, v \vee}$, SRI HENDRASTUTI HIDAYAT ${ }^{2}$, \\ AWANG MAHARIJAYA ${ }^{3}$ \\ ${ }^{1}$ Plant Breeding and Biotechnology Graduate Program, Department of Agronomy and Horticulture, Faculty of Agriculture, Institut Pertanian Bogor. J1. \\ Meranti, Kampus IPB Darmaga, Bogor 16680, West Java, Indonesia. Tel. +62-251-8629354, Fax.+62-251-8629352, ^dyah_sayekti@apps.ipb.ac.id \\ ${ }^{2}$ Department of Plant Protection, Faculty of Agriculture, Institut Pertanian Bogor. Jl. Meranti, Kampus IPB Darmaga, Bogor 16680, West Java, Indonesia \\ ${ }^{3}$ Department of Agronomy and Horticulture, Faculty of Agriculture, Institut Pertanian Bogor. Jl. Meranti, Kampus IPB Darmaga, Bogor 16680, West \\ Java, Indonesia. Tel.: +62-251-8629354, Fax.: +62-251-8629352, "vemail: muhsyukur@apps.ipb.ac.id
}

Manuscript received: 11 September 2021. Revision accepted: 12 October 2021.

\begin{abstract}
Sayekti TWDA, Syukur M, Hidayat SH, Maharijaya A. 2021. Morphological response and genetic variability of four species of chili pepper (Capsicum spp.) under infection of pepper yellow leaf curl virus. Biodiversitas 22: 4758-4765. Chili pepper has various types and species, but only five known species are commonly used and consumed. Most cultivated chili is susceptible to various plant diseases, one of which is Pepper yellow leaf curl disease (PYLCD) caused by Pepper yellow leaf curl virus (PYLCV) (Begomovirus, Geminiviridae). To control PYLCD, resistant variety assembly is required to prevent virus infection in cultivated plants. From this research, testing on four chili species is expected to provide information regarding the resistance and performance of chili peppers to conditions infected with PYLCV. This study was conducted at Dramaga Bogor, West Java, Indonesia in two experimental units: planting under virus-free conditions (as control) and virus-infected conditions. Each experimental unit was carried out using a single factor Randomized Complete Block Design (RCBD) with three replications. Twenty-nine genotypes of chili pepper were used consisted of four species, including $C$. annuиm, $C$. frutescens, $C$. chinense, and $C$. baccatum. Of the 29 genotypes tested, thirteen genotypes in the resistant, nine genotypes in moderate resistant, two genotypes in moderate susceptible, three genotypes in the Susceptible, and two genotypes in the highly susceptible category. The heritability, genotypic coefficient of variance (GCOV) and phenotypic coefficient of variance $(\mathrm{PCOV})$ value obtained from testing for all characters is high, ranging from $65.16-99.12 \%, 14.87-82.60 \%$, and $15.77-84.45 \%$, respectively. Most of the genotypes from $C$. chinense showed good resistance to PYLCV. In general, by considering the category of the resistance level and other characters such as productivity, 'Jolokia' $(C$. chinense), 'Anies' $(C$. annuum) and 'Bonita' $(C$. frutescens) can be ascertained as potential candidate sources of resistance to PYLCV.
\end{abstract}

Keywords: Begomovirus, chili pepper, heritability, morphology, resistance

\section{INTRODUCTION}

The world community has placed chili pepper (Capsicum spp.) as one of the essential horticultural commodities. We can find the use of chili pepper in every aspect of human life. The World Vegetable Center (WVC)/The Asian Vegetable Development and Research Center (AVRDC) has stored 286 accessions of chili pepper in 1986. This number has increased in 30 years until now; the number of collections owned by WVC has reached 8264 accessions, including accessions from at least 100 countries worldwide (Jarret et al. 2019). In addition, The Vegetable Research and Development Center (TVRC), Kasetsart University, Thailand, is also known to have collected 2827 accessions of chili pepper from all over Thailand in 1989 (Mongkolporn and Taylor 2011). Most of these accessions have been characterized conventionally and using molecular markers for various characters (Munoz-Concha et al. 2020), such as agronomic characters, fruit quality, and resistance to virus attack (Nankar et al. 2020). Chili pepper has various types and species, but until now, only five known species are commonly used and consumed by the public, namely Capsicum annuиm, $C$. frutescens, C. baccatum, C. chinense, and C. pubescens.
Most of the chili genotypes are susceptible to various diseases, one of which is Pepper yellow leaf curl disease (PYLCD) caused by Pepper yellow leaf curl virus (PYLCV) (Begomovirus, Geminiviridae) (Sulandari et al. 2007). Infection of PYLCV can be recognized from its symptoms; thickening of the leaf bones, curly leaves, yellowing, and stunting (Sulandari et al. 2006; Gaswanto et al. 2016). Transmission of PYLCV occurs through whitefly (Bemisia tabaci) as a vector. Control of this disease is more directed at suppressing the population of vector insects, but it has not been effective in preventing the spread of PYLCV. According to Barchenger et al. (2019), assembling resistant plants is an effective way to control the spread of PYLCD.

Creating disease-resistant varieties requires sources of resistance traits. Sources of resistance to several members of Begomovirus have been extensively explored in various crops such as tomatoes (Yan et al. 2018), legumes (Blair and Morales 2008), and cotton (Zaidi et al. 2019). Likewise, many explorations and studies have been related to the resistance traits of chili pepper to PYLCV. Several sources of resistance to PYLCV were reported in several chili genotypes of the $C$. chinense species, including 'Bhut Jolokia' (Adluri et al. 2017). 
Although the source of resistance to PYLCV has been identified from several chili plants, there have not been many chili genotypes that are fully resistant to PYLCV. These phenomena are thought to be due to the high potential for mixed infection and recombination/pseudorecombination of Begomovirus (Singh et al. 2016). Mixed infection of several types of Begomovirus in one plant can cause an increase in the level of symptoms that are more severe than a single virus infection, while recombination or pseudo-recombination events can trigger new viral strains (Garcia-Gano et al. 2006; Mohamed 2010). This condition can then cause the breakdown of resistance of chili plants against PYLCV (Singh et al. 2016; Rubio et al. 2020). This shows that exploration is still needed to obtain information on the source of chili resistance properties against PYLCV. Through characterization, resistance testing and genetic analysis involving four chili species, it is hoped that data and information can be obtained about the level of resistance and performance of chili peppers under PYLCVinfected conditions.

\section{MATERIALS AND METHODS}

\section{Study area and genetic material}

This study was conducted at Dramaga Bogor, West Java, Indonesia (192 $\mathrm{m}$ asl). Plants were grown in a greenhouse with an average temperature of 24.7-32.9 ${ }^{\circ} \mathrm{C}$ and relative humidity of 49.2-82.2\%.

Twenty-nine genotypes of chili pepper were used, consisted of five species included $C$. annuum, $C$. frutescens, $C$. chinense, and $C$. baccatum. The genetic materials of chili pepper that were used in this experiment are shown in Table 1. This experiment was carried out using two experimental units: planting under virus-free conditions (as control) and virus-infected conditions. Each unit was arranged in a randomized complete block design (RCBD) with three replications. In each trial unit, ten plants were used for biological replication. Transmission of PYLCV was done using The Whitefly (Bemisia tabaci) as a vector.

\section{Procedures}

Vector preparation

Whitefly (Bemisia tabaci) was used as the vector for PYLCV transmission. The vectors were taken from chili pepper and eggplant gardens around the research site. Before being used for inoculation, the imago of whitefly from the field was maintained on virus-free cotton plants for a month to reproduce. Virus-free whitefly offsprings produced were used in the PYLCV transmission process.

\section{Inoculation}

Seeds of twenty-nine genotypes of chili pepper were sown in the seedling trays for two weeks or until the seedling reached the two-leaf phase. The well-growth seedling was transplanted to individual pots with a diameter of $20 \mathrm{~cm}$ and a height of $15 \mathrm{~cm}$. Inoculation was done ten days after transplanting. Virus transmission was done using an individual inoculation procedure (Ganefianti
2010). In this experiment, we allowed $24 \mathrm{~h}$ of acquisition access feeding (AAF) followed by $48 \mathrm{~h}$ of inoculation access feeding (IAF). After the inoculation process was done, then the whitefly was eradicated. To ensure the plant was infected, plants were inoculated with ten whiteflies per plant.

Plants were observed for symptom development every day from one to sixty days post-inoculation. The symptom was scored and classified using a severity scale, 0 corresponds to healthy plant (no symptom); 1 for yellowing symptom; 2 for yellowing and curling symptoms; 3 for yellowing, curling, and cupping symptoms; and 4 for yellowing, curling, cupping and stunting symptoms. The score was then used to determine the severity of the disease of each genotype using the following formula:

$$
\mathrm{DSI}=\left[\left(\operatorname{sum}\left(\mathrm{n}_{\mathrm{i}} \times \mathrm{Z}_{\mathrm{i}}\right)\right) /(\mathrm{N} \times \mathrm{Z})\right] \times 100 \%
$$

Where: DSI: Disease Severity Index; ni: class frequency; zi: assessment class score; $\mathrm{N}$ : number of plants observed; Z: maximum disease index. Plant resistance was categorized into five categories: Resistant $(0 \leq \mathrm{DSI} \leq$ $10 \%)$, Moderately Resistant (10<DSI $\leq 20 \%)$, Moderately Susceptible $(20<$ DSI $\leq 30 \%)$, Susceptible $(30<$ DSI $\leq$ $50 \%$ ) and Highly Susceptible (DSI > 50\%). In addition to observing the symptoms of TYLCV attack, we also observed morphological, agronomic, and yield components of the chili pepper genotypes.

Table 1. The genetic material of 30 chili pepper

\begin{tabular}{ll}
\hline Genotype & Species \\
\hline Yuni & C. annuum \\
IPBC12 & C. annuum \\
IPBC15 & C. annuum \\
Ungara & C. annuum \\
Anies & C. annuum \\
Seloka & C. annuum \\
SSP & C. annuum \\
IPBC5 & C. annuum \\
IPBC3 & C. annuum \\
F5-012328-6-2-1 & C. annuum \\
F5-012328-1AB-2-1 & C. annuum \\
F5-012328-6-2-2 & C. annuum \\
F4-012328-1AB-3 & C. annuum \\
F4-012328-3-3 & C. annuum \\
F6-074 & C. annuum \\
F1 Baja & C. annuum \\
Caman & C. annuum \\
Adelina & C. annuum \\
IPBC333 & C. frutescens \\
IPBC290 & C. frutescens \\
Bonita & C. frutescens \\
Taruna & C. frutescens \\
Cakra Putih & C. frutescens \\
Red Habanero & C. chinense \\
Jolokia & C. chinense \\
Fatali & C. chinense \\
Red Chupetinho & C. chinense \\
Bishop Crown & C. chinense \\
Lemon Drop & C. baccatum \\
\hline &
\end{tabular}




\section{Data analysis}

For qualitative characters, data were presented descriptively, and cluster analysis was performed. Quantitative character's data were subjected to analysis of variance, estimation of genetic parameters, and heritability estimates. The analysis of variance was conducted following the procedure of Steel and Torrie (1981). Estimation of genetic parameters and heritability was done by following methods of Lush (1949) and Johnson et al. (1955) (Table 2):

$$
\begin{aligned}
& \sigma_{\mathrm{G}}^{2}=(\mathrm{M} 2-\mathrm{M} 3) / \mathrm{r} \\
& \sigma^{2} \mathrm{e}=\mathrm{M} 3 \\
& \sigma^{2}=\sigma^{2}{ }_{\mathrm{G}}+\sigma^{2} \mathrm{e} \\
& \mathrm{h}^{2} \mathrm{bs}=\left(\sigma^{2}{ }_{\mathrm{G}} / \sigma^{2}{ }_{\mathrm{P}}\right) \times 100 \%
\end{aligned}
$$

Criteria of heritability (\%) (Whirter 1979) are: low (0< $X<20 \%)$, moderate $(20 \leq X<50 \%)$ and high $(X \geq 50)$.

\section{RESULTS AND DISCUSSION}

\section{Qualitative character performance}

Seventeen qualitative characters were observed, which showed a polymorphic pattern among genotypes. These characters included seedlings, stems, leaves, flowers, and fruit characters. Seedling characters were hypocotyl color consisted of green (23 genotypes), white (5 genotypes), and purple (1 genotype). Cotyledonous leaf shape comprised of lanceolate (18 genotypes), deltoid (2 genotypes), elongdeltoid (7 genotypes), and ovate (2 genotypes). Cotyledonous leaf color ranged from green to yellowishgreen. Leaf shape fell into lanceolate (7 genotypes), deltoid ( 7 genotypes), and ovate (15 genotypes).

The flower position consisted of erect (15 genotypes), intermediate (5 genotypes), and pendant (9 genotypes). Fruit position comprised of erect (11 genotypes), intermediate (5 genotypes), and pendant (13 genotypes) while corolla color was white (21 genotypes), greenishwhite (6 genotypes), and purple (2 genotypes). Sepals color fell into green ( 27 genotypes) and purple (2 genotypes) while anther color was categorized into gray (11 genotypes), greyish-green (1 genotype), purple (3 genotypes), green (7 genotypes), purplish-grey (1 genotype), purplish-white (4 genotypes), and yellow (2 genotypes). Number of Corolla: 5-crowns (11 genotypes), 6-crowns (11 genotypes), 5/6-crowns (6 genotypes), and 7crowns (1 genotype).

Fruit shape was classified into elongate (14 genotypes), triangular (4 genotypes), campanulate (5 genotypes), and blocky (6 genotypes). Fruit shape at pedicle attachment included acute (1 genotype), obtuse (15 genotypes), truncate (7 genotypes), cordate (1 genotype), and lobate (5 genotypes). Fruit shape at blossom end consists of pointed
(19 genotypes), blunt (3 genotypes), sunken (5 genotypes), and sunken and pointed ( 2 genotypes). Fruit cross-sectional corrugation fell into slightly corrugated (24 genotypes), intermediate (1 genotype), and corrugated (4 genotypes). The fruit surface was smooth (20 genotypes), semiwrinkled (8 genotypes), and wrinkled (1 genotype).

Cluster analysis was performed involving 17 polymorphic characters and they are presented in Figure 1. Cluster analysis showed that the 29 genotypes used were generally divided into two main clusters and several sub clusters. Partition of the clusters based on the similarity level of 0.625 produced five different clusters. Cluster I consisted of 22 genotypes from 3 different species, i.e., $C$. аппиит ('Yuni', 'SSP', 'IPBC3', 'F6-074', 'IPBC12', 'Anies', 'IPBC5', 'F1 Baja', 'Caman', 'Seloka', 'Adelina', 'IPBC15', 'F5-012328-6-2-2', 'F5-012328-1AB-2-1', 'F5012328-6-2-1', 'F4-012328-1AB-3', 'F4-012328-3-3', and 'IPBC333'), and C. frutescens ('IPBC333', 'IPBC290', 'Bonita', and 'Taruna'). Cluster II consisted of four genotypes from C. chinense species ('Fatali', 'Jolokia', 'Red Chupetinho', and 'Red Habanero'). Cluster III, Cluster IV, and Cluster V each consisted of one genotype, namely, 'Ungara' (C. annuum), 'Bishop Crown' ( $C$. chinense), and 'Lemon Drop' (C. baccatum), respectively.

\section{Genetic variability}

Analysis of variance revealed a significant genotype effect on all observed variables (Table 3). This result shows that there is a diversity of characters among the tested genotypes. The wide range of each character supports this claim. The mean value of the leaf length ranged from 5.00 cm ('Yuni') to $15.96 \mathrm{~cm}$ ('White Chakra'). The average leaf width ranged from $1.94 \mathrm{~cm}$ ('Yuni') to $9.34 \mathrm{~cm}$ ('Bishop's Crown'). The stem diameter ranged from $0.46 \mathrm{~cm}$ ('Caman') to $0.88 \mathrm{~cm}$ ('IPBC290' and 'Fatali'). The mean plant height ranged from $45.26 \mathrm{~cm}$ ('Ungara') to $126.67 \mathrm{~cm}$ ('IPBC290'). The fruit length ranged from $1.89 \mathrm{~cm}$ ('Ungara') to $16.15 \mathrm{~cm}$ ('Caman'). The diameter of the test genotype fruit ranged from $0.78 \mathrm{~cm}$ ('Yuni') to $3.92 \mathrm{~cm}$ ('Bishop Crown'). The observed fruit weights ranged from $1.30 \mathrm{~g}$ ('Red Chupetinho') to $15.36 \mathrm{~g}$ ('F4-012328-1AB-3'). The number of fruits per plant of the tested genotype under PYLCV-infected conditions ranged from 0 ('Adelina') to 42.6 ('Red Chupetinho'). The yield per plant of the tested genotype varied from $0 \mathrm{~g}$ ('Adelina') to $69.98 \mathrm{~g}$ ('Anies'). Disease severity index varied from $0 \%$ ('Adelina', 'Red Habanero', 'Red Chupetinho') to 75.0\% ('Lemon Drop'). The coefficient of variance (CV) is the ratio of the standard deviation to the mean of a variable (Pena-Yam et al. 2019). The coefficient of variation from the test results shows a low value of less than 20\% (Gomez and Gomez 1987) on all variables except for the disease severity index (25.51\%), which indicates that the test results are valid.

Table 2. F-Ratios was used to test the effects for randomized complete block experiments

\begin{tabular}{lcc}
\multicolumn{1}{c}{ Sources of variation } & Mean square & Expected mean squares (fixed model) \\
\hline Replication (Rep) & M1 & - \\
Genotype (Geno) & M2 & $\sigma^{2} \mathrm{e}+\mathrm{r} \sigma^{2} \mathrm{G}$ \\
Error & $\mathrm{M} 3$ & $\sigma^{2} \mathrm{e}$ \\
\hline
\end{tabular}

Note: $\sigma^{2} \mathrm{e}$ : environmental variance; $\sigma^{2} \mathrm{G}$ : genotypic variance 


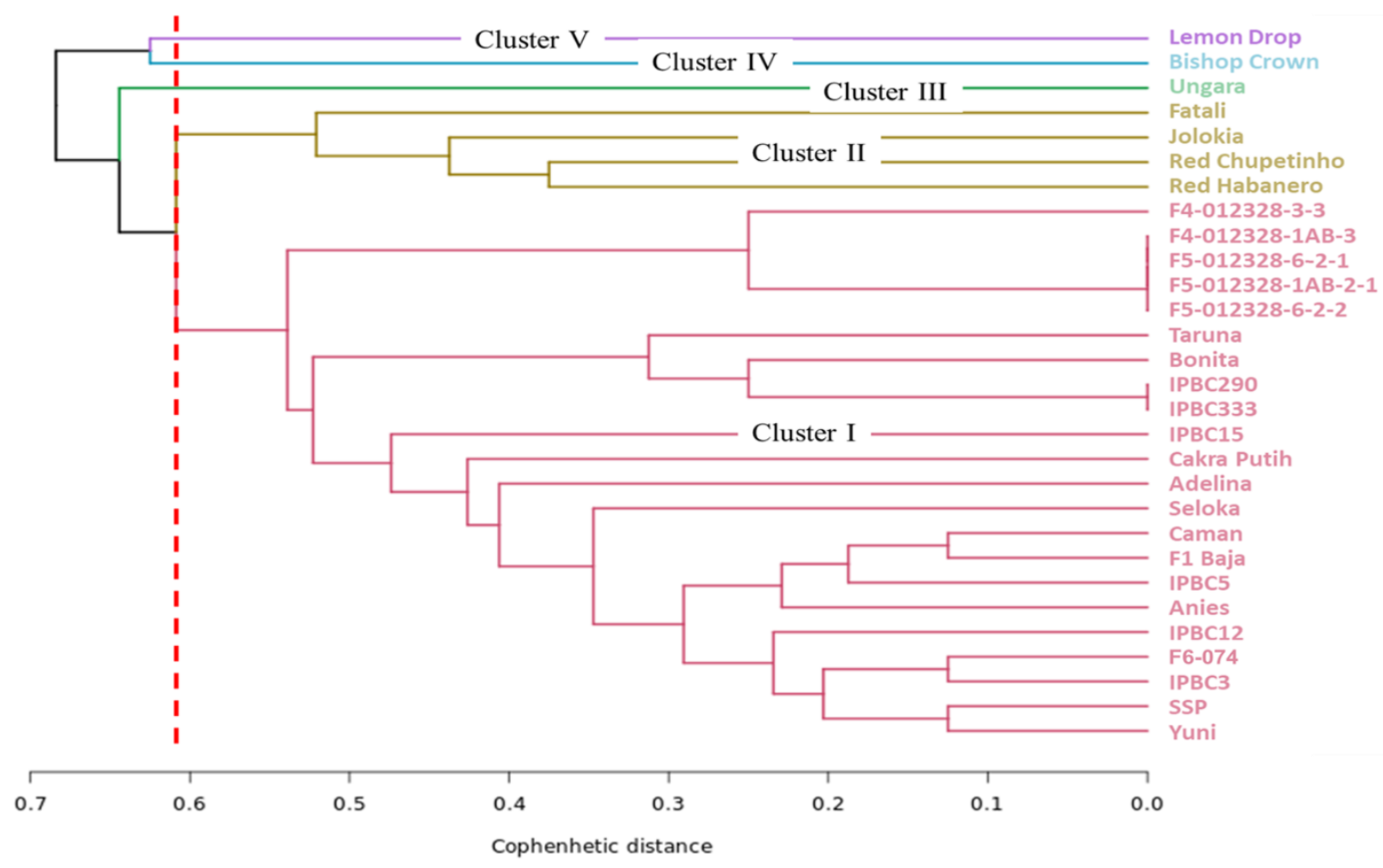

Figure 1. Dendrogram showing the relationships among chili pepper genotypes using 17 qualitative traits

The results of the analysis of variability and heritability are presented in Table 4 . The value of genotypic variance is greater than twice the standard deviation value $\left(\sigma^{2}{ }_{\mathrm{G}}>2 \sigma\right.$ $\left(\sigma_{\mathrm{G}}^{2}\right)$ ). This result shows that the genetic diversity of each character is quite wide. The value of the observed phenotypic variance is greater than the genotypic variance, so it can be seen that the diversity of chili plant characters is not only influenced by genetic factors but is also influenced by the environment. To estimate the proportion of the influence of genetic factors on plant phenotype characters, an approach that can be taken is to estimate the heritability value of the related characters. The heritability value obtained from testing for all characters is high, ranging from 65.16 to $99.12 \%$. Heritability value indicates the proportion of genetic factors in influencing the performance of a character (phenotype). The high heritability value can confirm that the genetic diversity most influence the observed phenotype variation in each tested genotype.

The genotypic coefficient of variance (GCOV) and phenotypic coefficient of variance (PCOV) are presented in Table 5. The results of the analysis showed that PCOV values were higher than GCOV in all characters, indicating that the diversity of characters in plants is influenced by both genetic and environmental factors (Terfa and Gurmu 2020). All observed characters had high GCOV values $(>20 \%)$ except for stem diameter, which was in the moderate category (15.77\%). GCOV and PCOV values are grouped into three categories: low $(<10 \%)$, moderate $(10-$ $20 \%$ ), and high $(>20 \%)$ (Terfa and Gurmu 2020; Hamidou et al. 2018).

Table 3. Estimation of the mean square for different parameters of Begomovirus infected chili pepper

\begin{tabular}{|c|c|c|c|c|}
\hline \multirow{2}{*}{ Character } & \multirow[b]{2}{*}{ Range } & \multicolumn{2}{|c|}{ Mean Square } & \multirow{2}{*}{ CV $(\%)$} \\
\hline & & Rep & Geno & \\
\hline Leaf length $(\mathrm{cm})$ & $5.00-15.96$ & $0.0097^{\mathrm{ns}}$ & $24.1346^{* *}$ & 3.36 \\
\hline Leaf width $(\mathrm{cm})$ & $1.96-9.34$ & $0.0147^{\mathrm{ns}}$ & $12.4521^{* *}$ & 3.41 \\
\hline Stem diameter $(\mathrm{cm})$ & $0.46-0.88$ & $0.0015^{\mathrm{ns}}$ & $0.0351^{* *}$ & 5.39 \\
\hline Plant height $(\mathrm{cm})$ & $45.26-126.67$ & $13.3544^{\mathrm{ns}}$ & $1853.5198^{* * *}$ & 4.65 \\
\hline Fruit length $(\mathrm{cm})$ & $1.89-16.15$ & $0.589^{\mathrm{ns}}$ & $40.9159^{* *}$ & 14.47 \\
\hline Fruit diameter $(\mathrm{cm})$ & $0.78-3.92$ & $0.0258^{\mathrm{ns}}$ & $3.292^{* *}$ & 11.35 \\
\hline Fruit weight (g) & $1.30-15.36$ & $0.1513^{\text {ns }}$ & $53.9417^{* *}$ & 9.04 \\
\hline Number of fruit per plant & $0.00-42.60$ & $1.2835^{\mathrm{ns}}$ & $268.0011^{* * *}$ & 17.59 \\
\hline Yield per plant (g) & $0.00-68.98$ & $15.0792^{\mathrm{ns}}$ & $594.7606^{* *}$ & 15.91 \\
\hline Disease severity $(\%)^{\mathrm{T}}$ & $0.00-75.00$ & $0.0218^{\mathrm{ns}}$ & $0.0767^{* *}$ & 25.51 \\
\hline
\end{tabular}

Note: Geno: Genotype; Rep: Replication; CV: Coefficient of Variance $* *$ significant at level of 1\%; 5\%; ns: not significant; $\mathrm{T}=$ transformed data is used 
Table 4. Genetic variability and heritability of Begomovirus infected chili pepper

\begin{tabular}{|c|c|c|c|c|c|c|}
\hline Character & $\sigma_{G}^{2}$ & $2 \sigma\left(\sigma_{G}^{2}\right)$ & Criteria of $\sigma_{G}^{2}$ & $\sigma_{P}^{2}$ & $h^{2} b s(\%)$ & Criteria of $h^{2} b s$ \\
\hline Leaf length & 7.99 & 7.08 & Wide & 8.14 & 98.19 & High \\
\hline Leaf width & 4.13 & 3.65 & Wide & 4.18 & 99.12 & High \\
\hline Stem diameter & 0.01 & 0.01 & Wide & 0.01 & 88.91 & High \\
\hline Plant height & 613.08 & 543.63 & Wide & 627.35 & 97.72 & High \\
\hline Fruit length & 13.37 & 12.00 & Wide & 14.16 & 94.39 & High \\
\hline Fruit diameter & 1.08 & 0.97 & Wide & 1.13 & 96.03 & High \\
\hline Fruit weight & 17.82 & 15.82 & Wide & 18.30 & 97.40 & High \\
\hline Number of fruit per plant & 88.00 & 78.61 & Wide & 91.99 & 95.66 & High \\
\hline Yield per plant & 187.83 & 174.56 & Wide & 219.09 & 85.73 & High \\
\hline Disease severity & 0.02 & 0.01 & Wide & 0.03 & 65.16 & High \\
\hline
\end{tabular}

Note: $\sigma^{2}$ : phenotypic variance; $\sigma_{\mathrm{G}}^{2}$ : genotype variance; $\sigma\left(\sigma_{\mathrm{G}}^{2}\right)$ : stdev of genotypic variance; $\mathrm{h}^{2} \mathrm{bs}$ : broad sense heritability

Table 5. Estimated genotypic and phenotypic coefficient of variation of Begomovirus infected chili pepper

\begin{tabular}{|c|c|c|c|c|}
\hline Character & $\operatorname{GCOV}(\%)$ & Criteria of GCOV & PCOV (\%) & Criteria of PCOV \\
\hline Leaf Length & 24.84 & High & 25.06 & High \\
\hline Leaf Width & 36.12 & High & 36.28 & High \\
\hline Stem Diameter & 14.87 & Moderate & 15.77 & Moderate \\
\hline Plant Height & 30.51 & High & 30.86 & High \\
\hline Fruit Length & 59.41 & High & 61.15 & High \\
\hline Fruit Diameter & 55.85 & High & 57.00 & High \\
\hline Fruit Weight & 80.16 & High & 81.22 & High \\
\hline Number of Fruit per Plant & 82.60 & High & 84.45 & High \\
\hline Yield per Plant & 39.02 & High & 42.14 & High \\
\hline Disease Severity & 34.91 & High & 43.24 & High \\
\hline
\end{tabular}

Note: PCOV: phenotypic coefficient of variance; GCOV: genotypic coefficient of variance

\section{Plant resistance level}

The incubation period and disease severity of the 29 genotypes tested are shown in Table 6 . The results showed a diversity of resistance levels among the tested genotypes. The PYLCV resistance level of chili peppers were divided into five categories, i.e., resistant, moderately resistant, moderately susceptible, susceptible, and highly susceptible.

The incubation period of the disease in each genotype varied from 5 to 45 DAI. The genotypes 'Adelina', 'Red Habanero', and 'Red Chupetinho' showed no symptoms of PYLCD during the observation period. Of the 29 genotypes tested, thirteen genotypes were classified into the Resistant category ('Adelina', 'Red Habanero', 'Red Chupetinho', 'F6-074', 'Jolokia', 'Fatali', 'F5-012328-6-2-1', 'Anies', 'F4-012328-1AB-3', 'F5-012328-1AB-2-1', 'Caman', 'IPBC3', and 'IPBC290'), nine genotypes were categorized as moderately resistant ('F1 Baja', 'Seloka', 'Bonita', 'IPBC12', 'F4-012328-3-3', 'Ungara', 'F5-012328-6-2-2', 'IPBC15', and 'Cakra Putih' ), two genotypes were classified in moderately susceptible category ('Taruna' and 'IPBC333'), three genotypes were in the Susceptible category ('SSP', 'Bishop Crown', and 'IPBC5') and two genotypes were in the highly susceptible category ('Yuni' and 'Lemon Drop').

The yield reduction in resistant genotypes, namely 'Adelina' (C. annuum) (100\%), 'Red Habanero' (55.80\%), and 'Red Chupetinho' (47.63\%), was relatively high. The Jolokia and Bishop Crown (C. chinense) genotypes showed a minor decrease in yield per plant, which only reached
$20.87 \%$ and $21.81 \%$ respectively.

\section{Discussion}

In assembling disease-resistant plants, apart from focusing on plant resistance, other traits that are not directly related also need to be developed to support increased yields and product quality. Sources of diversity are increasingly being explored, not only limited to the same species or commodity but also from other commodities (Beam and Ascencio-Ibanez 2020). Evaluation of various species becomes important to be carried out to obtain good sources of morphological, agronomic, and resistance character.

Evaluation of morphological and agronomic characters, in this study, was carried out on plants that had been inoculated with PYLCV. Qualitative characters were observed on normal plant organs that did not show symptoms of PYLCD. Qualitative characters are generally controlled by major genes and only slightly influenced by the environment (Seprico 2020), so viral infection is thought not to change these qualitative characters much. For the quantitative characters, plant characters that appear in the phenotype result from the influence of plant genetics and the environment. To determine the proportion of genetic influence in the diversity of characters, it can be seen through the heritability values of each observed character. High heritability values were observed in all the characters studied in this experiment. Heritability is the degree of genetic control associated with some important 
traits (Usman et al. 2014) that indicates how much of the genetic variability has a genetic origin and gives the necessary information for the genetic selection process (Usman et al.2017). This high value shows that most of the diversity that exists in the population is influenced by genetic factors.

In addition, in this study, genotypes from four species were used. These species differences led to a wide morphological diversity among the test genotypes. This diversity is shown in the heritability value. Compared to other characters, the disease severity character has a lower heritability value $(65.16 \%)$. This is presumably because environmental influences have more roles in influencing the disease severity compared to other characters. According to (Sing et al. 2016), the disease severity in plants does not only depend on genetic factors related to plant resistance. Environmental factors, the interaction of insect vectors with the host, and viral recombination can significantly change plant resistance and affect the development of disease symptoms (Rubio et al. 2020). This assumption is supported by a high $\mathrm{CV}$ value, which indicates that factors other than genetics significantly affect disease severity.
The difference between PCOV and GCOV shows how much the environment influences the observed characters. In this study, the difference between PCOV and GCOV was small in all characters, which indicates that the characters were slightly influenced by environmental factors, except for the disease severity character, which has a large difference between PCOV and GCOV. Since PCOV estimates the genotypes and environment effects, the higher difference between GCOV and PCOV indicates a significant contribution of the environment through the interaction between genotypes and environment. This experiment cannot observe these interactions. The highest GCOV and PCOV values were obtained on fruit weight and the number of fruits per plant. The same results were also obtained in a study conducted by Paul et al. (2017) in Linseed plant (Linium usitatissimum L.), Adhikari et al. (2018) in rice (Oryza sativa), and Pena-Yam et al. (2019) and Ajith and Manju (2006) in chili, thus supporting the results of this study. The high GCOV supported by high heritability indicates that the diversity of characters in the population was high, and the selection of these characters should be possible (Hamidou et al. 2018).

Table 1. Resistance level and productivity of 29 chili pepper infected by Pepper Yellow Leaf Curl Virus

\begin{tabular}{|c|c|c|c|c|c|}
\hline Genotype & $\begin{array}{c}\begin{array}{c}\text { Incubation } \\
\text { period } \\
\text { (DAI) }\end{array} \\
\end{array}$ & $\begin{array}{l}\text { Disease severity } \\
\text { index }(\%)\end{array}$ & Yield per plant & $\begin{array}{c}\text { Percentage } \\
\text { reduction of yield } \\
\text { per plant }\end{array}$ & Category \\
\hline Adelina & - & 0.00 & $0.00^{\mathrm{P}}$ & $100.00^{\mathrm{a}}$ & Resistant \\
\hline Red Habanero & - & 0.00 & $34.45^{\mathrm{f}-\mathrm{k}}$ & $55.80^{\mathrm{g}-\mathrm{k}}$ & Resistant \\
\hline Red Chupetinho & - & 0.00 & $48.09^{\text {cde }}$ & $47.63^{\mathrm{i}-1}$ & Resistant \\
\hline F6-074 & $22-26$ & 3.33 & $48.85^{\text {cde }}$ & $60.18^{e-j}$ & Resistant \\
\hline Jolokia & 38 & 3.33 & $23.81^{\mathrm{k}-\mathrm{n}}$ & $20.87^{\mathrm{m}}$ & Resistant \\
\hline Fatali & 35 & 3.33 & $18.93^{\mathrm{mn}}$ & $34.80^{\mathrm{lm}}$ & Resistant \\
\hline F5-012328-6-2-1 & 39 & 5.83 & $34.17^{\mathrm{f}-\mathrm{k}}$ & $51.78^{\mathrm{h}-\mathrm{k}}$ & Resistant \\
\hline Anies & 16 & 6.67 & $68.98^{\mathrm{a}}$ & $52.46^{\mathrm{h}-\mathrm{k}}$ & Resistant \\
\hline F4-012328-1AB-3 & 28 & 7.50 & $52.87^{\mathrm{bcd}}$ & $46.80^{\mathrm{i}-1}$ & Resistant \\
\hline F5-012328-1AB-2-1 & 45 & 7.50 & $43.77^{\mathrm{def}}$ & $63.73^{\mathrm{d}-\mathrm{i}}$ & Resistant \\
\hline Caman & $16-21$ & 8.33 & $30.75^{\mathrm{h}-1}$ & $62.04^{\mathrm{d}-\mathrm{i}}$ & Resistant \\
\hline IPBC3 & 12 & 10.00 & $29.16^{\mathrm{j}-\mathrm{m}}$ & $75.94^{\mathrm{b}-\mathrm{e}}$ & Resistant \\
\hline IPBC290 & 15 & 10.00 & $28.95^{\mathrm{j}-\mathrm{m}}$ & $64.55^{\mathrm{c}-\mathrm{h}}$ & Resistant \\
\hline F1 Baja & $12-13$ & 10.83 & $55.47^{\mathrm{bc}}$ & $53.92^{\mathrm{h}-\mathrm{k}}$ & Moderately resistant \\
\hline Seloka & $16-18$ & 11.67 & $42.57^{\mathrm{efg}}$ & $77.43^{b}$ & Moderately resistant \\
\hline Bonita & 15 & 13.33 & $41.38^{\text {efg }}$ & $46.93^{\mathrm{jkl}}$ & Moderately resistant \\
\hline IPBC12 & $12-19$ & 15.00 & $35.59^{f-j}$ & $54.92^{\mathrm{g}-\mathrm{k}}$ & Moderately resistant \\
\hline F4-012328-3-3 & 24 & 15.00 & $18.57^{\mathrm{mn}}$ & $71.69^{\mathrm{b}-\mathrm{g}}$ & Moderately resistant \\
\hline Ungara & $22-25$ & 16.67 & $30.49^{\mathrm{h}-1}$ & $31.71^{\mathrm{lm}}$ & Moderately resistant \\
\hline F5-012328-6-2-2 & $25-27$ & 16.67 & $39.25^{\mathrm{e}-\mathrm{i}}$ & $42.26^{\mathrm{kl}}$ & Moderately resistant \\
\hline IPBC15 & $15-18$ & 18.33 & $17.59^{\mathrm{n}}$ & $80.24^{\mathrm{bc}}$ & Moderately resistant \\
\hline Cakra Putih & 12 & 20.00 & $26.06^{\mathrm{j}-\mathrm{n}}$ & $57.76^{\mathrm{f}-\mathrm{k}}$ & Moderately resistant \\
\hline Taruna & 12 & 20.83 & $20.77^{\mathrm{Imn}}$ & $62.62^{\mathrm{d}-\mathrm{j}}$ & Moderately susceptible \\
\hline IPBC333 & 12 & 25.00 & $25.04^{j-n}$ & $66.53^{\mathrm{c}-\mathrm{h}}$ & Moderately susceptible \\
\hline SSP & $26-29$ & 30.83 & $28.70^{\mathrm{j}-\mathrm{m}}$ & $70.78^{\mathrm{c}-\mathrm{g}}$ & Susceptible \\
\hline Bishop Crown & 26 & 31.67 & $40.38^{\mathrm{e}-\mathrm{h}}$ & $21.81^{\mathrm{m}}$ & Susceptible \\
\hline IPBC5 & 25 & 44.17 & $59.35^{\mathrm{b}}$ & $71.58^{\mathrm{b}-\mathrm{g}}$ & Susceptible \\
\hline Yuni & $5-8$ & 51.67 & $32.34^{\mathrm{g}-\mathrm{k}}$ & $73.41^{\mathrm{b}-\mathrm{f}}$ & Highly susceptible \\
\hline Lemon Drop & 41 & 75.00 & $6.95^{\circ}$ & $87.97^{\mathrm{ab}}$ & Highly susceptible \\
\hline
\end{tabular}

Note: Number followed by the same letter in the same column were not significantly different to DMRT 5\% level; DAI: Day After Inoculation;-: no symptoms appear until the end of the observation period 
The resistance characters observed in this study included the incubation period and the disease's severity. The incubation period (the time between inoculation and symptom expression) and latent period (the time between inoculation and infectiousness of the house) have not been widely documented. If disease control is based on visual symptoms, the incubation period is important because it is related to the time of symptom appearance (Rimbaud et al. 2015). Control can be done quickly when the virus incubation period in cultivated plants is quickly seen. On the other hand, visual symptoms tend to be attractive to vectors. Viruses that cause visual symptoms can cause changes in the production and emission of volatile organic compounds or changes in nutrients and defense chemistry, which are important cues for insect vectors and affect vector feeding (Mauck et al. 2012). That is how the incubation period is thought to have a role in disease spread in the field.

Three genotypes ('Adelina', 'Red Habanero', and 'Red Chupetinho') showed no PYLCD symptoms until the end of the observation period. Plants may not show symptoms after being infected with the virus if they have complete resistance or partial resistance to prevent the development of the virus in plant tissues (Rubio et al. 2020). Fruit weight per plant in conditions infected with Begomovirus generally decreased compared to control (virus-free plants). 'Adelina' has no fruit until the end of the observation period due to flower loss and fruit formation failed to occur. This phenomenon is thought to be one of the consequences of PYLCD attacks, where Rusli et al. (1999) reported that one of the symptoms of PYLCD is flower loss. In addition, according to Harth et al. (2016), pollen reduction will occur in virus-infected plants so that fertilization does not happen, and no fruit is formed.

'Jolokia' is included in resistant plants with a long incubation period (38 DAI) and low DSI (3.33\%). These results align with Adluri et al. (2017) who stated that the 'Bhut Jolokia' ( $C$. chinense) genotype was thought to have good resistance to PYLCV. The Bishop Crown genotype was categorized as susceptible but under PYLCV-infected conditions, its yield reduction per plant was relatively low. Four of the five chili genotypes of the tested $C$. chinense species ('Red Habanero,' 'Red Chupetinho', 'Jolokia' and 'Fatali') had good resistance to PYLCV. These $C$. chinense species genotypes can be used as a source of resistance against PYLCV.

The genotype 'IPBC12' was included in the moderately resistant category, which in previous studies (Ganefianti 2010; Ayu 2019), 'IPBC12' included in the resistant category. This change in the resistance levels can be caused by several factors including changes in plant genetics (López-Fabuel et al. 2013) and differences in the infecting virus strains (Miras et al. 2014). The genotype 'F1 Baja' (C. annuum) was found to be moderately resistant in the present study, which is in line with its varietal description in the Decree of the Ministry of Agriculture Number 014/kpts/SR.120/D.2.7/2/2016. Out of 29 chili genotypes evaluated, two genotypes from the $C$. annuum species show a better resistance level than the 'F1 Baja', i.e., 'F6-074' and 'Anies'. In addition, 'Bonita' (C. frutescens) can also be considered to have better resistance than the other genotype from $C$. frutescens, and it has a lower yield reduction per plant. These three genotypes also can be used as sources of chili pepper resistance against PYLCD.

This study revealed a wide genetic diversity among the tested genotypes in almost all the observed variables, thus enabling the breeders to select genotypes with desirable characters from the existing population. Most of the genotypes from $C$. chinense have good resistance and can be developed as a source of chili pepper resistance against PYLCV. The genotypes 'Red Habanero', 'Red Chupetinho', 'Jolokia', and 'Fatali' were resistant to PYLCV while the 'Bishop Crown' was classified susceptible but still be able to produce well. In general, by considering the resistance level and other characters such as productivity, 'Jolokia' (C. chinense), 'Anies' (C. annuum) and 'Bonita' ( $C$. frutescens) genotypes can be recommended as candidate sources of good resistance to PYLCV.

\section{ACKNOWLEDGEMENTS}

The authors would like to acknowledge the Indonesian Directorate General of Higher Education for financial support (under PMDSU Research Grant financial year 2021 No. 077/SP2H/LT/DRPM/2021). The author would like to thank all parties who helped in data collection and work on this research.

\section{REFERENCES}

Adhikari BN, Joshi BP, Shrestha J, Bhatta NR. 2018. Genetic variability, heritability, genetic advance and correlation among yield and yield component of rice (Oryza sativa L.). J Agric Nat Resour 1 (1): 149160. DOI: 10.3126/janr.v1i1.22230

Adluri PK, Baldoldiya GM, Nath PD. 2017. Screening of bhut jolokia (Capsicum chinense Jacq.) germplasm of North East India against chilli leaf curl virus. Int J Pure Appl Biosci 5 (4): 1189-1196. DOI: 10.18782/2320-7051.5624

Ajith PM, Manju P. 2006. Genetic variation for yield and anthracnose resistance in chilli (Capsicum апnиит L.). Indian J Genet 66 (2): 161162.

Ayu DK. 2019. Resilience Response on Pepper to Yellow Leaf Curl Disease and Identification of Resistance gene Analogs. [Thesis]. Bogor Agricultural University, Bogor. [Indonesian]

Barchenger DW, Yule S, Jeeatid N, Lin SW, Wang YW, Lin TH, Chan YL, Kenyon L. 2019. A novel source of resistance to pepper yellow leaf curl Thailand virus (PepYLCThV) (Begomovirus) in chile pepper. HortScience 54 (12): 2146-2149. DOI: 10.21273/HORTSCI14484-19

Beam K, Ascencio-Ibanez. 2020. Geminivirus resistance: A minireview. Front Plant Sci 11: 1131. DOI: 10.3389/fpls.2020.01131

Blair MW, Morales FJ. 2008. Geminivirus resistance breeding in common bean. In: Prespectives in Agriculture Veterinary Science, Nutrition and Natural Resources. CABI Wallingford.

Ganefianti DW. 2010. Genetics of Resistance on Chilli Pepper to Yellow Leaf Curl Begomovirus and Strategy Breeding. [Disertation]. Bogor Agricultural University, Bogor. [Indonesian]

Garcia-Gano E, Resende RO, Fernandez-Munoz R, Moriones E. 2006. Synergistic interaction between tomato chlorosis virus and tomato spotted wilt virus result in breakdown of resistance in tomato. Virology 96 (11): 1263-1269. DOI: 10.1094/PHYTO-96-1263

Gaswanto R, Syukur M, Hidayat SH, Gunaeni N. 2016. Symptom and host range identification of six Chilli Begomovirus isolate in Indonesia. J Hortic 26 (2): 223-234. [Indonesian] 
Gomez AK, Gomez AA. 1987. Statitically Procedures for Agricultural Research Second Edition. John Willey and Sons Inc., Canada.

Hamidou M, Souley MKM, Kapran I, Soleymane O, Danquah EY, Ofori K, Gracen V, Ba MN. 2018. Genetic variability and its implications on early generation sorghum lines selection for yield, yield contributing traits, adn resistance to sorghum midge. Int J Agron 2018: 1864797. DOI: 10.1155/2018/1864797

Harth JE, Winsor JA, Weakland DR, Nowak KJ, Ferrari MJ, Stephenson AG. 2016. Effects of virus infection on pollen production and pollen performance: Implication for the spread of resistance alleles. Am J Bot 103 (3): 577-583. DOI: 10.3732/ajb.1500165

Jarret RL, Barboza GE, Batista FRC, Berke T, Chou YY, Hulse-Kemp A, Ochoa-Alejo N, Tripodi P, Veres A, Garcia CC et al. 2019. Capsicum-an abbreviated compendium. J Ammer Soc Hort Sci 144 (1): 3-22. DOI: $10.21273 / \mathrm{JASHS} 04446-18$

Johnson WW, Robinson HF, Comstock RE. 1955. Genotypic and phenotypic correlations in soybeans and their implications in selection. Agron J 47: 477-482. DOI: 10.2134/agronj1955.00021962004700100008x

López-Fabuel I, Wetzel T, Bertolini E, Bassler A, Vidal E, Torres LB Yuste A, Olmos A. 2013. Real-time multiplex RT-PCR for the simultaneous detection of the five main grapevine viruses. J Virol Methods 188: 21-24. DOI: 10.1016/j.jviromet.2012.11.034

Lush JL. 1949. Heritability of quantitative characters in farm animals Hereditas 35: 356-375. DOI: 10.1111/j.1601-5223.1949.tb03347.x

Mauck K, Bosque-Perez NA, Eigenbrode SD, De Moraes CM, Mescher MC. 2012. Transmission mechanism shape pathogen effects on host vector interaction: Evidence from plant viruses. Funct Ecol 26: 1162 1175. DOI: 10.1111/j.1365-2435.2012.02026.x

Miras M, Sempere RN, Kraft JJ, Miller WA, Aranda A, Truniger V. 2014 Interfamilial recombination between viruses led to acquisition of a novel translation-enhancing RNA element that allows resistance breaking. New Phytol 202: 233-246. DOI: 10.1111/nph.12650

Mohamed EF. 2010. Interaction between some viruses which attack tomato (Lycopersicon esculentum Mill.) plants and their effect on growth and yield of tomato plants. Am J Sci 6 (8): 311-320.

Mongkolporn O, Taylor PWJ. 2011. Capsicum. In: Kole C (ed). Wild Crop Relatives: Genomic and Breeding Resources Vol: Vegetables $1^{\text {st }}$ Edn. Springer, New York.

Munoz-Concha D, Quinones X, Hernandez JP, romero S. 2020. Chilli pepper landrace survival and family farmers in central chile. Agronomy 10: 1541-1558. DOI: 10.3390/agronomy10101541

Nankar AN, Todorova V, Tringovska I, Pasev G, Radeva-Ivanova V, Ivanova V, Kostova D. 2020. A step towards Balkan Capsicum anпиит L. core collection: Phenotypic and biochemical characterization of 180 accessions for agronomic fruit quality, and virus resistance traits. PLoS One 15 (8): e0237741. DOI: 10.1371/journal.pone.0237741

Paul S, Kumar N, Kumar A. 2017. Characterization and genetic variation study among linseed (Linium usitatissimum L.) genotypes for seed yield and related traits in Mid-Hills of North-West Himalayas. Plant Archive 17 (1): 407-411.

Pena-Yam LP, Munoz-Ramirez LS, Aviles-Vinas SA, Canto-Flick A, Perez-Pastrana J, Guzman-Antonio A, Santana-Buzzy N. 2019.
Analysis of genetic parameters of habanero pepper (Capsicum chinense Jacq.) in Yucatan, Mexico. HortScience 54 (3): 429-433. DOI: 10.21273/HORTSCI13710-18

Rimbaud L, Dallot S, Delaunay A, Borron S, Soubeyrand S, Thebaud G, Jacquot E. 2015. Assessing the mismatch between incubation and latent periods for vector-borne disease: the case of Sharka. Phytopathology 105 (11): 1408-1416. DOI: 10.1111/nph.12650

Rubio L, Galipienso L, Ferriol I. 2020. Detection of plant viruses and disease management: Relevance of genetic diversity and evolution. Front Plant Sci 11: 1092-1114. DOI: 10.3389/fpls.2020.01092

Seprico D. 2020. Beyond quantitative and qualitative traits: Three telling cases in the life sciences. Biol Philos 35 (3): 34-59. DOI: 10.1007/s10539-020-09750-6

Singh KA, Kushwaha N, Chakraborty S. 2016. Synergistic interaction among begomoviruses leads to the suppression of host defense-related gene expression and breackdown of resistance in chilli. Appl Microbiol Biotechnol 100 (9): 4035-4049. DOI: 10.1007/s00253-0157279-5

Steel RGD, Torrie JH. 1981. Principles and Procedures of Statistics: A Biometrical Approach. $2^{\text {nd }}$ Ed. McGrwa Hill Book, New York.

Sulandari S, Hidayat SH, Suseno R, Harjosudarmo J, Sosromarsono S. 2007. Inoculation of pepper yellow leaf curl virus on various plants and detection of the virus in its insect vector Bemisia tabaci Genn. (Hemiptera: Aleyrodidae). Proceeding of The Third Asian Conference on Plant Pathology. Gajah Mada University 20-24 August 2007.

Sulandari S, Suseno R, Hidayat SH, Harjosudarmo J, Sosromarsono S. 2006. Detection and host range study of virus associated with pepper yellow leaf curl disease. Hayati 13 (1): 1-6. [Indonesian]

Terfa GN, Gurmu GN. 2020. Genetic variability, heritability and genetic advance in lindseed (Linum usitatissium L.) genotypes for seed yield and other agronomic traits. Oil Crop Sci 5: 156-160. DOI: 10.1016/j.ocsci.2020.08.002

Usman MG, Rafii MY, Ismail MR, Malek MA, Latif MA. 2014 Heritability and genetic andvance among chili pepper genotypes for heat tolerance and morphophysiological characteristics. Sci World J 2014: 308042. DOI: 10.1155/2014/308042

Usman MG, Rafii MY, Martini MY, Oladosu Y, Pedram K. 2017. Genotypic character relationship and phenotypic path coefficient analysis in chili pepper genotypes grown under tropical condition. J Sci Food Agric 97 (4): 1164-1171. DOI: 10.1002/jsfa.7843

Whirter KS. 1979. Breeding of cross-pollinated crops. In: Knight. R (ed). A Course Manual in Plant Breeding. Australian Vide-Chanceller's Committee, Brisbanen.

Yan Z, Perez-de-Castro A, Diez MJ, Hutton SF, Visser RG, Wolters AMA, Bai Y, Li J. 2018. Resistance to tomato yellow leaf curl virus in tomato genrmplasm. Front Plant Sci 9: 1198. DOI: 10.3389/fpls.2018.0119

Zaidi SSA, Naqvi RZ, Asif M, Strickler S, Shakir S, Shafiq M, Khan AM, Amin I, Mishra B, Mukhtar MS et al. 2019. Molecular insight into cotton leaf curl geminivirus disease resistance in cultivated cotton (Gossypium hirsutum). Plant Biotechnol J 18 (3): 691-706. DOI: 10.1111/pbi.13236 